\title{
Researching Eighth Grade Students' Science Achievement based on 21st Century Skill Levels and Some Variables
}

\author{
Research Article
}

\section{Hatice MERTOGLU1', Esra DIKER AKMAN²}

${ }^{1}$ Marmara University, Faculty of Education, Istanbul, Turkey, ORCID: 0000-0002-3172-7443

${ }^{2}$ Ministry of Education, Teacher, Istanbul, Turkey, ORCID: 0000-0003-4411-298X

To cite this article: Mertoglu, H., \& Diker Akman, E. (2020). Researching Eighth Grade Students' Science Achievement based on 21st Century Skill Levels and Some Variables, International Online Journal of Educational Sciences, 12(3), 256-267.

\section{ARTICLE INFO \\ Article History:}

Received: 28.12.2019

Available online:

23.07.2020

\begin{abstract}
It has been a requirement of this era to have the 21st century skills. Also, with the development of technology, achievemet in life sciences and mathematics is being more significant every day. TIMSS exam arranged to determine this achievement, contributes the improvement and development of education. TIMMS also defines the success ranking among the countries. In this study, the relationship between the 21st century skills and TIMSS exam results declared in 2015 were investigated in relation with the variables; education level of parents of the students taking the exam, participants' expactaions from educational life, taking private science courses. With the purpose of understanding the impact of these variables on TIMSS exam results, this study was completed with 418 students from three districts in İstanbul in 2018-2019 academic year selected by randomly sampling method. The normality distributions of data groups were examined by KolmogorovSmirnov and Shapiro-Wilk tests with obtained data. The data were collected using TIMSS 2015 life sciences achievement test, demographic information of the students and 21st century skills scale. As a result of the analysis, it is determined that there is a statistically significant relationship between the science achievements of the students and parents' education level, the expectation from educational life and taking private science course. No significant relationship is determined between TIMSS science achievement and 21st century skill levels.
\end{abstract}

(C) 2020 IOJES. All rights reserved

Keywords:

TIMSS 2015, Science achievement, 21st Century Skills

\section{Introduction}

Developments of science and technology lead to significant economic and political changes in countries. At the same time, this development also facilitates access to scientific knowledge and enables individuals to gain high level creativity (Çakmak, 2008). Since the beginning of education; the importance of teaching basic

\footnotetext{
${ }^{1}$ Corresponding author's address: Marmara University

Telephone: 5334755462

e-mail: hatice.mertoglu@marmara.edu.tr

DOI: https://doi.org/10.15345/iojes.2020.03.018
} 
concepts such as reading, writing and mathematics was strongly emphasized. However, although such skills remain important today, recent studies have been focusing on teaching children 21st century skills (Larson \& Miller, 2011).

When 20th century is compared with 21st century, the competencies that people need in areas such as work, citizenship, realisation of yourself are quite different from each other. The reason for this difference is primarily the development of communication and information technologies in a very complicated way in the 21st century (Dede, 2009). The individuals living in knowledge based society should have skills such as problem solving, creative and critical thinking. At the same time, information processing skills including research, analysis and synthesis should be considered as key competencies (Myunghee, Heeok, II-Hyun, Jongho \& Jeonghee, 2010).

One of the most important requirements of the social, economic and cultural progress of the countries is the training of the individuals in accordance with the requirements of the era. Due to the continuous development of the information and technology, the education and training of individuals need to be regularly updated. The comparison of educational outcomes in different countries with our country guides development of methodology and objectives in our education and training system. One way of obtaining comparative data in education system is to participate in international measurement and evaluation studies such as PISA, TIMSS, PIRLS and TALIS. Within this context, International Mathematics and Science Trends Study (TIMSS-Trends in Mathematics and Science Study), provides important data in secondary school level (Çetin, 2016).

International student achievement research has been used since the early 1990s in order to compare countries' own education systems with each other. International Trends in Mathematics and Science StudyTIMSS is one of these studies. It has been conducted in every four years since 1995. It is organised by International Association for the Evaluation of Educational Achievement-IEA, an organisation performing international measurement and evaluation. It measures the achievement of fourth and eighth grade students in science and mathematics in the participating countries. In addition, a quesitionnaire is applied to the students, parents and teachers and a research is performed for the items related with the variables associated with the achievement of the students. Data obtained from TIMSS application guides to researchers and to those preparing the education program and leads to obtain information from educational programs of the countries which had successful results (Bayraktar, 2010).

By the help of "TIMSS science achievement" test, which provides important data for the determination of success and demonstrates the success among countries, success of the students was determined. Turkey remained below the overall average each year attended (Martin, Gregory and Stemler, 2000; Şişman, Acat, Aypay and Karadağ, 2011; Büyüköztürk, Çakan, Tan and Atar, 2014; Yıldırım, Özgürlük, Parlak, Gönen and Polat, 2016). The aim of the education system is not only to equip the students with academic knowledge but also to ensure that they grow as social, active, versatile, productive individuals. For this purpose, it is very important to measure the 21st century skill levels of the students. The aim of this study is to measure students' 21st century skill levels and TIMSS science achievements. Based on this purpose, following research questions addressed in the research.

1. What is the level of 21st century skills of 8 th grade students?

2. Does TIMSS science achievement differ according to parental education level?

3. Does TIMSS science achievement differ according to the expectations of students from their educational life? 
4. Does TIMSS science achievement differ according to the availability of science supplementation outside the school?

5. Is there a significant relationship between 21st century skill levels and TIMSS science achievement of 8 th grade students in secondary school?

\section{Method}

In this research, relational screening model was used. In the screening model, the relationships between the variables can be examined. According to Karasar (2016), "Relational screening models are research models aiming to determine the existance and/or degree of covariance between two or more variables" (Karasar, 2016). In accordance with this explanation, relational screening model was used in this research to determine whether there is a relationship between 21st century skill levels and TIMSS science results.

\section{Research Participants}

Participants of this research consist of 418 8th grade students who were randomly selected from three districts in İstanbul. Two of them are in the Asian side, Ümraniye, Kadıköy and one is in the European side Kağıthane. All participants in the study were volunteer in 2018-2019 academic year.

\section{Data Collection}

In this research the data were obtained from a questionnaire consisting of three parts. In the first part, a personal information form of 10 questions developed by the researchers was used to determine some demographic characteristics of the students. In the second part, 21st Century Skills Scale developed by Kang, Kim, Kim and You (2012) and adapted to Turkish and analysed for validity and reliability by Karakas (2015) was used to determine the 21st century skill levels of the students. The reliability coefficient of the scale consisting of 32 items was found to be 0,90. In the third part, a test consisting of TIMSS 2015 8th Grade Science Questions declared to examine the students' TIMSS science achievement scores take part. There are 15 questions in TIMSS science test. In the scoring, correct answers were evaluated as (1) wrong answers as (0). After the reliability analysis of TIMSS 8th Grade Science Questions consisting of 15 questions Cronbach"s Alpha coefficient $(\alpha)$ was found to be 0,878 . This value indicates that the level of reliability of the questions is high and can be used for the study.

In order to implement the three different data collection tools used in this study, prior permission were obtained from the Provincial Directorate of National Education. Then, scales were applied to randomly selected classes in the schools that accepted to participate the study.

\section{Data Analysis}

Whole data collected from 8th grade secondary school by Personal Information Form, 21st Century

Skills Scale and TIMSS 2015 8th Grade Science Test, were transferred to SPSS 23.0 for Windows and analysed statistically.

Kolmogorov-Smirnov (K-S) and Shapiro-Wilk tests were used to investigate the normality distributions of data groups. The data group to show a normality distribution $p$ value should be as $p>.05$ (Pallant, 2005, p.57). 


\section{Findings}

Findings Related to 21st Century Skill Levels of Secodary School 8th Grade Students

Table 1. Descriptive statistics related to the 21st century Skills Scale

\begin{tabular}{lcl}
\hline Size/Scale & $\bar{X}$ & ss \\
\hline 21st Century Skillss Scale & 4,05 & 0,48 \\
\hline Cognitive Domain & 3,85 & 0,53 \\
\hline Affective Domain & 4,28 & 0,55 \\
\hline Socio-cultural Domain & 4,01 & 0,58 \\
\hline
\end{tabular}

The ruling skill levels of the students participated in the study were found to be the affective Domain. Affective Domain skill is followed by socio-cultural domain and cognitive domain. Overall 21st century skill levels of the students were also found to be high (Table 1).

\section{TIMSS Science Achievement Findings Aimed to Comparison of Parental Education Level}

According to non-parametric Kruskal-Wallis test conducted to investigate the effect of maternal education level on TIMSS science achievement (Table 2); education level of mother, causes significant difference between TIMSS science achievement scores of the students.

Table 2. The result of Kruskal-Wallis test aimed to comparison of TIMSS science achievement scores of students according to the education level of the mother

\begin{tabular}{|c|c|c|c|c|c|c|c|}
\hline \multirow{2}{*}{ Score } & \multirow{2}{*}{$\begin{array}{l}\text { Education } \\
\text { mother }\end{array}$} & \multicolumn{2}{|c|}{$\begin{array}{l}\text { Descriptive } \\
\text { Statistics }\end{array}$} & \multicolumn{2}{|c|}{ Kruskal-Wallis } & \multirow[b]{2}{*}{$p$} & \multirow[b]{2}{*}{ M-W } \\
\hline & & $\mathbf{n}$ & $\begin{array}{l}\text { Row } \\
\text { Average. }\end{array}$ & $X^{2}$ & $s d$ & & \\
\hline \multirow{5}{*}{$\begin{array}{l}\text { TIMSS } \\
\text { Science } \\
\text { Achievemet } \\
\text { Score }\end{array}$} & Illiterate(1) & 16 & 136,88 & \multirow{5}{*}{26,93} & \multirow{5}{*}{4} & \multirow{5}{*}{$0,000^{* * *}$} & \multirow{5}{*}{$\begin{array}{l}1 \text { and all } \\
5 \& 2,3,4\end{array}$} \\
\hline & Primary (2) & 128 & 211,10 & & & & \\
\hline & Secon. (3) & 120 & 193,48 & & & & \\
\hline & High Sch.(4) & 107 & 201,72 & & & & \\
\hline & Higher ed. (H/HE) (5) & 46 & 285,64 & & & & \\
\hline
\end{tabular}

According to the post-hoc Mann-Whitney $U$ test (Table 3) conducted to find the significant difference between the education groups, the TIMSS science achievement scores of the students whose mothers were illiterate were lower than all other students and TIMSS science achievement score of the students whose mothers were graduated from higher education were higher than the students whose mothers were graduated from primary, secondary and high school. 
Table 3. Post-hoc Mann-Whitney test on the educational status of the students' mothers

\begin{tabular}{|c|c|c|}
\hline (I) Educational status of mother & (J) Educational status of mother & $p$ \\
\hline \multirow{4}{*}{ Illiterate (1) } & Primary (2) & $0,000^{* * *}$ \\
\hline & Secondary (3) & $0,000^{* * *}$ \\
\hline & High Sch. (4) & $0,000^{* * *}$ \\
\hline & Higher education (H/HE) (5) & $0,000^{* * *}$ \\
\hline \multirow{4}{*}{ Primary (2) } & Illiterate $(1)$ & $0,000^{* * *}$ \\
\hline & Secondary (3) & 0,217 \\
\hline & High Sch. (4) & 0,453 \\
\hline & Higher education (H/HE) (5) & $0,004^{* *}$ \\
\hline \multirow{4}{*}{ Secondary (3) } & Illiterate $(1)$ & $0,000^{* * *}$ \\
\hline & Primary (2) & 0,217 \\
\hline & High Sch. (4) & 0,601 \\
\hline & Higher education ( H/HE ) (5) & $0,009^{* *}$ \\
\hline \multirow{4}{*}{ High Sch. (4) } & Illiterate $(1)$ & $0,000^{* * *}$ \\
\hline & Primary (2) & 0,453 \\
\hline & Secondary (3) & 0,601 \\
\hline & Higher education (H/HE) (5) & $0,007^{* *}$ \\
\hline \multirow{4}{*}{ Higher education (H/HE) (5) } & Illiterate $(1)$ & $0,000^{* * *}$ \\
\hline & Primary (2) & $0,004^{* *}$ \\
\hline & Secondary (3) & $0,009^{* *}$ \\
\hline & High Sch. (4) & $0,007^{* *}$ \\
\hline
\end{tabular}

${ }^{* *} p<.01,{ }^{* * *} p<.001$

According to non-parametric Kruskal-Wallis test conducted to investigate the effect of fahter education level on TIMSS science achievement (Table 4); father's education level was found to cause significant difference between the TIMSS science achievement scores of the students.

Table 4. The result of Kruskal-Wallis test aimed to comparison of TIMSS science achievement scores of students according to the education level of the father

\begin{tabular}{|c|c|c|c|c|c|c|c|}
\hline \multirow{2}{*}{ Score } & \multirow{2}{*}{ Educational status of father } & \multicolumn{2}{|c|}{ Descriptive Statis. } & \multicolumn{4}{|c|}{ Kruskal-Wallis } \\
\hline & & $\mathbf{n}$ & Row Ave. & $X^{2}$ & ssd & $p$ & M-W \\
\hline \multirow{5}{*}{$\begin{array}{l}\text { TIMSS Science } \\
\text { Achievement } \\
\text { Score }\end{array}$} & Illiterate (1) & 4 & 166,25 & \multirow{5}{*}{20,12} & \multirow{5}{*}{4} & \multirow{5}{*}{$0,000^{* * *}$} & \multirow{5}{*}{$\begin{array}{c}1,2 \text { and } 3,4,5 \\
3,4 \text { and } 5\end{array}$} \\
\hline & Primary (2) & 72 & 169,9 & & & & \\
\hline & Secondary (3) & 135 & 206,14 & & & & \\
\hline & High Sch. (4) & 139 & 208,65 & & & & \\
\hline & Higher education (H/HE) (5) & 67 & 266,43 & & & & \\
\hline
\end{tabular}

$\overline{* * *} p<.001$

According to the post-hoc Mann-Whitney $U$ test (Table 5) conducted to find the significant difference between the education groups, the TIMSS science achievement scores of the students whose fathers were illiterate and graduated from primary school were lower than other students whose fathers were graduated from secondary, high school and higher education and TIMSS science achievement score of the students whose fathers were graduated from higher education were higher than the students whose fathers were graduated from secondary and high school. 
Table 5. Post-hoc Mann-Whitney test on the educational status of the students' fathers

\begin{tabular}{|c|c|c|}
\hline (I) Educational status of father & (J) Educational status of father & $p$ \\
\hline \multirow{4}{*}{ Illiterate (1) } & Primary (2) & 0,866 \\
\hline & Secondary (3) &, $009^{* *}$ \\
\hline & High Sch. (4) & $0,006^{* *}$ \\
\hline & Higher education (H/HE) (5) & $0,000^{* * *}$ \\
\hline \multirow{4}{*}{ Primary (2) } & Illiterate (1) & 0,866 \\
\hline & Secondary (3) & $0,012^{*}$ \\
\hline & High Sch. (4) & $0,010^{*}$ \\
\hline & Higher education (H/HE) (5) & $0,000^{* * *}$ \\
\hline \multirow{4}{*}{ Secondary (3) } & Illiterate (1) &, $009^{* *}$ \\
\hline & Primary (2) & $0,012^{*}$ \\
\hline & High Sch. (4) & 0,902 \\
\hline & Higher education (H/HE) (5) & $0,000^{* * *}$ \\
\hline \multirow{4}{*}{ High Sch. (4) } & Illiterate (1) & $0,006^{* *}$ \\
\hline & Primary (2) & $0,010^{*}$ \\
\hline & Secondary (3) & 0,902 \\
\hline & Higher education (H/HE) (5) & $0,000^{* * *}$ \\
\hline \multirow{4}{*}{ Higher education (H/HE) (5) } & Illiterate (1) & $0,000^{* * *}$ \\
\hline & Primary (2) & $0,000^{* * *}$ \\
\hline & Secondary (3) & $0,000^{* * *}$ \\
\hline & High Sch. (4) & $0,000^{* * *}$ \\
\hline
\end{tabular}

${ }^{*} p<.05,{ }^{* *} p<.01,{ }^{* * *} p<.001$

\section{TIMSS Science Achievement Findings Aimed to Comparison of Expectations of students from} Edcuational Life

According to non-parametric Kruskal-Wallis test (Table 6) conducted to determine the significant difference between students' expectations from educational life and the TIMSS science achievement scores, the expectation from educational life causes a significant difference between students' TIMSS science achievement scores.

Table 6. The result of Kruskal-Wallis test aimed to comparison of TIMSS science achievement scores of students according to the expectations from edcuational life

\begin{tabular}{|c|c|c|c|c|c|c|c|}
\hline \multirow{2}{*}{ Score } & \multirow{2}{*}{$\begin{array}{l}\text { Expectation } \\
\text { from } \\
\text { educational } \\
\text { life }\end{array}$} & \multicolumn{2}{|c|}{ Descriptive Statis. } & \multicolumn{4}{|c|}{ Kruskal-Wallis } \\
\hline & & $\mathbf{n}$ & Sira Ort. & $X^{2}$ & $s d$ & $p$ & M-W \\
\hline \multirow{6}{*}{$\begin{array}{l}\text { TIMSS } \\
\text { Science } \\
\text { Achieveme } \\
\text { nt Score }\end{array}$} & Undecided (1) & 63 & 167,90 & \multirow{6}{*}{17,04} & \multirow{6}{*}{4} & \multirow{6}{*}{$0,002^{* *}$} & \multirow{6}{*}{$\begin{array}{c}1,2 \text { and } \\
4,5\end{array}$} \\
\hline & High sch. And & 8 & 163,63 & & & & \\
\hline & below (2) & & & & & & \\
\hline & $\begin{array}{l}\text { Associate } \\
\text { degree (3) }\end{array}$ & 41 & 188,80 & & & & \\
\hline & Licence (4) & 193 & 222,20 & & & & \\
\hline & $\begin{array}{l}\text { Masters/Docto } \\
\text { rate (5) }\end{array}$ & 113 & 229,12 & & & & \\
\hline
\end{tabular}

According to the post-hoc Mann-Whitney $U$ test conducted to find the source of this difference (Table 7); TIMSS science achievement score of the students' who want to do "undergraduate and graduate / 
doctorate" in the future is higher than those who are "undecided" and who want to do "high school and below" education.

Table 7. Post-hoc Mann-Whitney test on the expectations of the students from educatinal life

\begin{tabular}{lll}
\hline (I) Expectation & (J) Expectation & $p$ \\
\hline \multirow{4}{*}{ Undecided (1) } & High sch. and below (2) & 0,867 \\
\cline { 2 - 3 } & Associate degree (3) & 0,218 \\
\cline { 2 - 3 } & Licence (4) & $0,000^{* * *}$ \\
\cline { 2 - 3 } & Masters/Doctorate (5) & $0,000^{* * *}$ \\
\hline \multirow{4}{*}{ High sch. and below (2) } & Undecided (1) & 0,867 \\
\cline { 2 - 3 } & Associate degree (3) & 0,196 \\
\cline { 2 - 3 } & Licence (4) & $0,000^{* * *}$ \\
\cline { 2 - 3 } Associate degree (3) & Masters/Doctorate (5) & $0,000^{* * *}$ \\
\hline & Undecided (1) & 0,218 \\
\cline { 2 - 3 } & High sch. and below (2) & 0,196 \\
\cline { 2 - 3 } & Licence (4) & 0,165 \\
\cline { 2 - 3 } Licence (4) & Masters/Doctorate (5) & 0,121 \\
\hline \multirow{4}{*}{ Masters/Doctorate (5) } & Undecided (1) & $0,000^{* * *}$ \\
\cline { 2 - 3 } & High sch. and below (2) & $0,000^{* * *}$ \\
\cline { 2 - 3 } & Associate degree (3) & 0,165 \\
\cline { 2 - 3 } & Masters/Doctorate (5) & 0,711 \\
\hline & Undecided (1) & $0,000^{* * *}$ \\
\cline { 2 - 3 } & High sch. and below (2) & $0,000^{* * *}$ \\
\cline { 2 - 3 } & Associate degree (3) & 0,121 \\
\cline { 2 - 3 } & Licence (4) & 0,711 \\
\hline
\end{tabular}

$* * * x<.001$

TIMSS science achievement findings aimed to comparison of the Science Supplementation Outside the school

Table 8. The result of the t-test for comparison of the TIMSS science achievement scores of students according to getting private science course

\begin{tabular}{|c|c|c|c|c|c|c|c|c|}
\hline \multirow{2}{*}{ Score } & \multirow{2}{*}{$\begin{array}{l}\text { Getting } \\
\text { course }\end{array}$} & \multirow[t]{2}{*}{ private } & \multicolumn{3}{|c|}{ Descriptive Statistics } & \multicolumn{3}{|c|}{ t-test } \\
\hline & & & $\mathbf{n}$ & $\bar{X}$ & ss & $\mathbf{t}$ & sd & p \\
\hline TIMSS $\quad$ Science & Yes & & 162 & 10,91 & 3,44 & 2,99 & 416 & $0,000^{* * *}$ \\
\hline Achievement Score & No & & 256 & 9,42 & 3,76 & & & \\
\hline
\end{tabular}

${ }^{* * *} p<.001$

There was a significant difference between TIMSS science achievement scores of the students who are taking private science courses and who are not. TIMSS science achievement scores of the students taking private science courses from a private teacher/class are higher than those who do not take any private course (Table 8). 
Findings on the relationship between 21st century skill levels and TIMSS Science Achievements

Table 9. The correlation coefficient for the relationshsip between 21st century skill levels scores and TIMSS science achievement scores $(n=418)$

\begin{tabular}{|c|c|c|}
\hline Score & & $\begin{array}{l}\text { TIMSS Science } \\
\text { Achievement Score }\end{array}$ \\
\hline \multirow{2}{*}{ 21st century skill scale } & $r$ & 0,085 \\
\hline & $p$ & 0,082 \\
\hline \multirow{2}{*}{ Cognitive Domain } & $r$ & ,125* \\
\hline & $p$ & 0,011 \\
\hline \multirow{2}{*}{ Knowledge management skills } & $r$ & $171^{* * *}$ \\
\hline & $p$ & 0,000 \\
\hline \multirow{2}{*}{ Knowledge configuration skills } & $r$ & 0,054 \\
\hline & $p$ & 0,270 \\
\hline \multirow{2}{*}{ Use of knowledge skills } & $r$ & 0,024 \\
\hline & $p$ & 0,624 \\
\hline \multirow{2}{*}{ Problem solving skills } & $r$ & $129^{* *}$ \\
\hline & $p$ & 0,008 \\
\hline \multirow{2}{*}{ Affective Domain } & $r$ & 0,060 \\
\hline & $p$ & 0,218 \\
\hline \multirow{2}{*}{ Selfidentity } & $r$ & $-0,026$ \\
\hline & $p$ & 0,598 \\
\hline \multirow{2}{*}{ Self value } & $r$ & 0,068 \\
\hline & $p$ & 0,167 \\
\hline \multirow{2}{*}{ Self management } & $r$ & 0,055 \\
\hline & $p$ & 0,266 \\
\hline \multirow{2}{*}{ Self responsiblity } & $r$ & ,099* \\
\hline & $p$ & 0,043 \\
\hline \multirow[b]{2}{*}{ Socio-cultural Domain } & $r$ & 0,040 \\
\hline & $p$ & 0,411 \\
\hline \multirow{2}{*}{ Social membershp } & $r$ & 0,032 \\
\hline & $p$ & 0,517 \\
\hline \multirow{2}{*}{ Social sensitivitiy } & $r$ & 0,091 \\
\hline & $p$ & 0,062 \\
\hline \multirow{2}{*}{ Ability to socialize } & $r$ & 0,021 \\
\hline & $p$ & 0,663 \\
\hline \multirow{2}{*}{ Social performance (fulfillment) } & $r$ & $-0,016$ \\
\hline & $p$ & 0,745 \\
\hline
\end{tabular}

${ }^{*} p<.05,{ }^{* *} p<.01,{ }^{* * *} p<.001$

In Table 9 the coefficients of the Pearson moment multipilication correlations, which were made to examine the relationships between 21st century skill level scores and TIMSS science achievement scores of the students, are given. Obtained correlation coefficients were interpreted according to the following criteria (Jawlik, 2016, s.132).

\begin{tabular}{|c|c|}
\hline$r$ & relationship \\
\hline $0,00-0,10$ & None \\
\hline $0,10-0,30$ & Poor \\
\hline $0,30-0,50$ & Medium \\
\hline $0,50-0,70$ & Strong \\
\hline $0,70-1,00$ & Very strong \\
\hline
\end{tabular}


There was no significant relationship between the students' general 21st century skills and TIMSS science achievement scores ( $\mathrm{p}>$.05). In other words, 21st century skill levels of the students do not affect the TIMSS science achievement scores.

\section{Discussion}

In this study, relational screening model was used to determine whether there is a relationship between students' 21st century skill levels and TIMSS science results.

At the end of the study, 21st century skill levels of the students were found to be quite high. This result, overlaps with the study performed by Bozkurt and Çakır (2016). Similarly, they measured 21st century skill levels of secondary school students and found that they have master of 21st centruy skills.

In the research, it was concluded that the higher the education level of parents, the higher the achievement scores among participants were observed. It was determined that, the achievement scores of the students whose parents are illiterate or graduated from primary school are higher than than the students whose parents are graduated from secondary, high school or higher education. Uçar and Öztürk (2010), compared the data of Taiwan and Turkey which are the one of the successful countries in TIMSS exam and pointed out that the educational levels of the families in Taiwan were higher. Therefore, it is emphasised that, the education level of the family may be the one of the reasons of failure of students to achieve the desired result in TIMSS practice in Turkey. In his study investigating the factors affecting the science achievement based on the TIMSS data, informed the researchers that the educational level of the parents creates effective results in the sucess of their children. This result is like what Bayraktar (2010) and Abazaoğlu and Taşar (2016) found. They also declared similarly that there is statistically significant difference between the education status of the parents and the success of the students. These results are supported in the study.

Karaca (2018) stated that there is a relation between the achievement and the level of education that students plan for future. Kahraman (2014) concluded that students' feeling of belonging to the school increased the success. Abazaoğlu and Taşar (2016) determined that even one unit increase in the expectation from educational life increased the achievement scores of the students.

At the end of the research, it was found that students taking private courses were more successful that those not taking private course. Kaya and Kaya (2018), similarly, stated that taking extracurricular supplementation had a positive effect on success. Another result of the study is that 21st century skill levels do not affect science achievement. What comes to mind here is the high-self confidence of the students but the lack of any relationship between this self-confidence and success. Soner (2000), stated that the achievements scores did not differ with the students' self-confidence levels and the success in education was not related to self-confidence. It will be better if the self-confidence to be gained to the students is based on the success. In addition, another result of this study is that the students cannot implement the skills they think they have. In other words, it can be thought that, the students have the knowledge of 21st century skills but they cannot apply this knowledge in daily life. In their study, Turiman, Omar, Daud and Osman (2012), stated that the definition of success should be structured to include 21st century skills in order to be more successful in the future. He emphasized that the new tendency of education is to develop problem solving skills and to produce creative ideas. He also pointed out that, knowledge needs to be put into practice in order to keep up with the constantly renewed change due to globalization and technology. With this study, it can be said that students should not only have the mastery of skills but also synthesize them with some other achievements.

On of the reasons why the relationship between TIMSS science achievement and 21st century skill levels are low is thought to be caused by the incompatibility of the subject and question fields of the TIMSS questions and the cognitive fields of the curriculum and textbooks applied in our country. Students are particularly challenged in high-level reasoning questions. The percentage of giving right answers to TIMSS questions 
especially to those measuring reasoning skills, is lower than other areas (Büyüköztürk, Çakan, Tan and Atar, 2014; Yıldırım, Özgürlük, Parlak, Gönen and Polat, 2016). When Pektas, Incikabi and Yaz (2015), examined the questions found in the science textbooks, they stated that the majority of the questions were at the level of knowing and the number of reasoning questions were very limited. Cerit Berber (2015), compared the physics education program in Hong Kong and noted that in Hong Kong curriculum, more emphasis was given to activities with students. He said that this situation contributed to the high-level thinking skills of the students. Afacan and Nuhoğlu (2008), examined the questions in the application of TIMSS and high school entrance exam applied in our country and stated that the questions in the exam applied in our country cannot effectively measure the analysis, synthesis and evaluation steps. When these studies are taken into consideration, it is concluded that no matter how high is the 21st century skill levels of the students, since reasoning skills are not given much weight during the course, students can not make the questions in this field.

\section{Conclusion}

As a result of this study, 21st century skill levels of the students were found to be quite high. However, TIMSS science achievement was not found to be high on the same level and no correlation was found between students' TIMSS science achievement scores and 21st century skill levels. TIMSS questions mostly consist of reasoning questions. This suggests that, how high is the 21st century skill levels of the students, since reasoning skills are not given much weight during the course, students cannot maket he questions in this field. It can be said that this study is importat due to the determination of the necessity of performing studies on reasoning skills. In addition, it has been determined that student's achievement increases as the education level of the parents increases, as they set high goals for their careers and as supplementary science courses are taken outside the school. Implementation of informal education for adults, by providing regular guidance services to the students creating an awareness and help for setting goals for their own future and generalisation of taking extra courses outside the school in order to improve the learning process of the students can make positive contributions to student achievement. 


\section{REFERENCES}

Abazaoğlu, İ., \& Taşar, M. F. (2016). Fen bilgisi öğretmen özelliklerinin öğrenci fen başarısı ile ilişkisi: TIMSS 2011 verilerine göre bir durum analizi. Illköğretim Online (Elementary Education Online), 15(3), $922-945$.

Afacan, Ö., \& Nuhoğlu, H. (2008). Canlılar bilimi konusunda TIMSS-R (1999) soruları ile LGS (1999) sorularının karşılaştırmalı analizi. Ahi Evran Üniversitesi Kırşehir Eğitim Fakültesi Dergisi (KEFAD), 9(1), 31-43.

Bayraktar, Ş. (2010). Uluslararası Fen ve Matematik Çalışması (TIMSS 2007) Sonuçlarına Göre Türkiye'de Fen Eğitiminin Durumu. Selçuk Üniversitesi Ahmet Keleşoğlu Eğitim Fakültesi Dergisi. Sayı 30 (s. 249-270).

Bozkurt, Ş. B., \& Çakır, H. (2016). Ortaokul öğrencilerinin 21. yüzyıl öğrenme becerileri düzeylerinin cinsiyet ve sınıf seviyesine göre incelenmesi. PAU Ĕ̆itim Fakültesi Dergisi, (39): 69-82.

Büyüköztürk, Ş., Çakan, M., Tan, Ş., \& Atar, H. Y. (2014). TIMSS 2011 ulusal matematik ve fen raporu 4-8. sinıflar. Ankara: İşkur Publishing.

Cerit-Berber, N. (2015). Türkiye ve Hong Kong fizik öğretim programlarının karşılaştırılması. Necatibey Ĕ̆itim Fakültesi Elektronik Fen ve Matematik Ĕ̆gitimi Dergisi, 9(2), 61-84.

Çakmak, Ö. (2008). Eğitimin ekonomiye ve kalkınmaya etkisi. Dicle Üniversitesi Ziya Gökalp Ĕ̆itim Fakültesi Dergisi, 11, 33-41.

Çetin, B. (2016). TIMSS 2015 Ulusal matematik ve fen bilimleri ön raporu 4.ve 8.sinıflar. MEB, Ankara.

Dede, C. (2009). Comparing frameworks for 21st century skills. 01.05.2019 tarihinde http://sttechnology.pbworks.com/f/Dede_(2010)_Comparing\%20Frameworks\%20for\%2021st\%20Cent ury\%20Skills.pdf take in.

Kahraman, N. (2014). Cross-grade comparison of relationship between students' engagement and TIMSS 2011 science achievement. Education and Science, Vol.39, No.172, 95-107.

Kang, M., Heo, H., Jo, L., Shin, J., \& Seo, J. (2010). Developing an educational performance indicator for new millennium learners. Journal of Research on Technology in Education, 43(2), 157-170. https://doi.org/10.1080/15391523.2010.10782567

Karaca, F. (2018). Sekizinci sınıföğrencilerinin TIMSS matematik başarılarının bazı değişkenler açısından incelenmesi: Eskişehir ili örneği. (Yayımlanmamış Yüksek Lisans Tezi). Eskişehir Osmangazi University, Eskişehir.

Karakaş, M. M. (2015). Ortaokul sekizinci sınıf öğrencilerinin fen bilimlerine yönelik 21. yüzyıl beceri düzeylerinin ölçülmesi. Yayımlanmamış Yüksek Lisans Tezi. Eskişehir Osmangazi University, Institute of Educational Sciences, Eskişehir.

Karasar, N. (2016). Bilimsel Araştırma Yöntemi: Kavramlar-İlkeler-Teknikler. Nobel Yayın Dağıtım, Ankara.

Kaya, V. H., \& Kaya, E. (2018). Fen başarısını artırmak için ödevler ve kurslar gerekli midir? Anadolu Öğretmen Dergisi, 2(1), 48-62.

Larson, L. C., \& Miller, T. N. (2011). 21st century skills: prepare students for the future. Kappa Delta Pi Record, $47: 3,121-123$.

Martin, M. O., Gregory, K. D., \& Stemler, S. E. (2000). TIMSS 1999 technical report. International Study Center Lynch School of Education, Boston Collage.

Myunghee, K., Heeok, H., Il-Hyun, J., Jongho, S., \& Jeonghee, S. (2010). Developing and educational performance indicator for new millennium learners. Journal of Research on Technology in Education, 43(2), 157-170. 
http://ezproxy.library.usyd.edu.au/login?url=http://search.ebscohost.com/login.aspx?direct=true\&db= buh\&AN=55546001\&site=ehost-live taken in .

Öztürk, D., \& Uçar, S. (2010). TIMSS verileri kullanılarak Tayvan ve Türkiye'deki 8. sınıf öğrencilerinin fen başarışına etki eden faktörlerin belirlenmesi ve karşılaştırılması. Çukurova Üniversitesi Sosyal Bilimler Enstitüsü Dergisi, 19(3), 241-256

Pallant, J. (2005). SPSS Survival Manual. Allen \& Unwin. Australia.

Pektaş, M., İncikabı, L., \& Yaz, Ö. V. (2015). Ortaöğretim fen ders kitaplarının TIMSS çerçevesine göre analizi. Adryaman University Journal of Educational Sciences, 5(1), 29-48.

Soner, O. (2000). Aile uyumu, öğrenci özgüveni ve akademik başarı arasındaki ilişkiler. Marmara University Atatürk Faculty of Education Journal of Educational Sciences 12, 249-260.

Şişman M., Acat M.B., Aypay A., \& Karadağ E. (2011). TIMSS 2007 Ulusal matematik ve fen raporu sekizinci sinuflar. Ankara: MEB.

Turiman, P., Omar, J., Daud A. M., \& Osman, K. (2012). Fostering the 21st century skills through scientific literacy and science process skills. Procedia Social and Behavioral Sciences, 59, 110-116.

Yıldırım, A., Özgürlük, B., Parlak, B., Gönen, E. \& Polat, M. (2016). TIMSS 2015 Ulusal matematik ve fen bilimleri ön raporu dördüncü ve sekizinci sinıflar. Ankara: MEB. 